\title{
Description of Coffee Consumption Patterns at The Productive Age in The Times Covid-19 Pandemic
}

\author{
${ }^{1}$ Dwita Meylina Nur Aisyah, ${ }^{2}$ Farah Nurul Basma, ${ }^{3}$ Hanifah Sekar Wulandari, ${ }^{4}$ Munaya \\ Fauziah \\ Faculty of Public Health, Muhammadiyah University of Jakarta \\ K.H. Ahmad Dahlan St, Cireundeu, Ciputat, South Jakarta, 15419 \\ Email: dwtmyln.@gmail.com
}

\begin{abstract}
Background Coffee is one of the drinks that are often consumed by the people of Indonesia. In Indonesia, the age of coffee connoisseurs is almost irrespective of age ranging from teenagers to adults and even seniors, so there are countless. The tradition of drinking coffee, especially in the morning, is a habit of people every day. Based on the results of a survey conducted by Maspul in Kurniawan, et al (2020) it was found that during the COVID-19 pandemic, consumers were more likely to consume coffee drinks in the form of sachets which did not take long to serve. Furthermore, he stated that during the COVID-19 pandemic there was a tendency to increase consumption of ready-to-drink instant coffee such as cold coffee beverages, ready-to-drink coffee, and specialty instant coffee. Objective This study aims to describe the pattern of coffee consumption at productive age during the COVID-19 pandemic in 2021. Design descriptive research method with a qualitative approach to design cross-sectional. The sample in this study was three (3) female students and directed the research target to an effort to find a theory from the base (grand theory) which aims to understand the phenomena experienced by the research subjects. Result Characteristics of respondents The research was conducted with 3 respondents in the productive age group who will describe or construct in-depth interviews with research subjects so that they can provide a clear picture of coffee consumption patterns in productive ages during the COVID-19 pandemic.
\end{abstract}

Keywords: Coffee, consumption patterns, productive age, COVID-19 
E-ISSN: 2808-5361

http://e-journal.fkmumj.ac.id/
Proceeding The First

Muhammadiyah Internasional-

Public Health and Medicine

Conference

\section{INTRODUCTION}

Coffee has long been considered a hereditary drink that has many benefits to become the hallmark of the Indonesian people in the eyes of the foreign public. (Herlyana, 2012); (Prasodjo, 2016) This is because Indonesia is one of the best coffee bean producers in the world. Indonesia places coffee as one of the leading commodities plantations. The opportunity for the coffee industry in Indonesia is considered very good. Especially with the increasing recognition of Indonesian coffee in Europe and America, especially specialty coffee (specialty coffee) such as Gayo coffee, Mandailing coffee, Lampung coffee, Bajawa coffee, and others.

The number of coffee shops in Indonesia recorded in August 2019 reached more than 2950 outlets. Around. Meanwhile, based on the Center for Agricultural Data and Information Systems (2017), the national coffee consumption rate in 2016 reached around 250 thousand tons and grew by $10.54 \%$ to 276 thousand tons in 2017. Indonesian coffee consumption during the 2016-2021 period is predicted to grow at an average rate of an average of $8.22 \%$ per year. In the year 2021, the coffee supply is predicted to reach 795 thousand tons with a consumption of 370 thousand tons, resulting in a surplus of 425 thousand tons.

Coffee is wrong one a drink that is often consumed by the people of Indonesia. In Indonesia, the age of coffee connoisseurs is almost irrespective of age ranging from teenagers to adults and even seniors, so there are countless. The tradition of drinking coffee, especially in the morning, is a habit of people every day. However, nowadays it's not only in the morning, in between activities and busy schedules, but people also prefer to gather and drink coffee, for example during lunch breaks to be friends to spend their time. The tradition of drinking coffee is not only to quench thirst, but also to accompany life's activities community events such as reunions, dating, doing chores, and so on. This is what makes the trend of drinking coffee continue to increase sharply and unconsciously, this coffee drinking tradition has become part of a lifestyle trend. (Oktaviani, 2018)

For certain circles enjoying coffee is not just how to feel the sensation of sweet and bitter, but that activity will have a wider impact. For example, young executives will enjoy a cup of coffee by carrying out activities with business relations or continuing their work. Likewise with teenagers, enjoying a cup of coffee is only meaningful if it is done in a coffee shop interspersed with small discussions. (Oktaviani, 2018)

However, from February to June 2020, the world economy experienced a downturn when the COVID-19 Virus spread globally from China. The impact of the virus on the economic response has created the biggest shock to the Indonesian economy since the Asian financial crisis two decades earlier. (Olivia, Gibson, and Nasrudin, 2020) According to Apostolopoulos in Kurniawan, et al (2020) A total of fifty to ninety percent of coffee sales turnover from good coffee sales services from coffee shops that provide service "dine-in" or from outdoor outlets decreased. Fear appears in circle Public 
E-ISSN: 2808-5361

http://e-journal.fkmumj.ac.id/
Proceeding The First

Muhammadiyah Internasional-

Public Health and Medicine

Conference

to transmission of the virus as a result of the presence of contact with the outside environment and from crowd mass. (Kurniawan, Wahyu and Nurbaya, 2020)

Based on the survey results done by Maspul in Kurniawan, et al (2020) found that during the COVID-19 consumers are more likely to consume coffee drinks in the form of sachets which do not take long to serve. Furthermore, he stated that during the COVID-19 pandemic, there was a tendency to increase consumption of ready-to-drink instant coffee such as cold coffee beverages, ready-to-drink coffee, and specialty instant coffee. Coffee consumers view that during a pandemic like today, instant coffee consumption is the best choice rather than having to visit coffee shops because it aims to reduce the spread of the virus in public places. (Kurniawan, Wahyu and Nurbaya, 2020)

\section{METHODS}

This study aims to describe the pattern of coffee consumption at age productive in times pandemic COVID-19. Type study qualitative use approach design sample triangulation to find out an overview of coffee consumption patterns. This research was conducted to the age group productive in the area of each researcher and carried out on 22-23 May 2021, with data collection through interviews.

Qualitative research was conducted from May 2021 to June 2021 using a descriptive observational study research design, namely conducting in-depth interviews using interview guidelines stated in words or writing and reviewing documents.

There is 3 informant which interviewed in May 2021, taking the sample is carried out through online via telecommunication. Source The information or informant in this study is someone who has entered the productive age group. Informants who will conduct in-depth interviews are those who consume coffee before and during the pandemic period COVID-19. Informant which chosen based on capacity to explain aimin. In this study, the informants had the initials PM (21), FD (21), and NN (20).

There are two types of data sources used in this study, namely primary data and secondary data. Primary data is specifically carried out to answer research questions. The writer collects primary data by method surveys and observations. As for secondary data obtained from data collection techniques that support primary data. This study was obtained from the results of observations made by the author as well as from literature studies related to this research.

Data validity was done by the triangulation method. To keep the validity of data, to determine data validity in this research used triangulation method. Triangulation of the method is carried out by using in-depth interviews with predetermined informants and reviewing documents from the description of coffee consumption patterns that have been made in previous studies. Researchers use this triangulation to ensure accuracy informant which collected. 
E-ISSN: 2808-5361

http://e-journal.fkmumj.ac.id/
Proceeding The First

Muhammadiyah Internasional-

Public Health and Medicine

Conference

Processing and analysis of qualitative data in this study were carried out with the data transcript stage where the data was transferred in the written form completely without changing, add or subtract the information contained in the record. Then a descriptive data analysis was carried out so that conclusions were obtained from the data that had been processed by coding on each data the answers of the sources contained in table 1. Results of Interview data analysis.

\section{RESULTS AND DISCUSSION}

Characteristics of respondents The research was conducted with 3 respondents in the productive age group who will describe or construct in-depth interviews with respondents subject

study so that could give description which clears regarding the pattern of coffee consumption at productive age during the COVID-19 pandemic.

The type of coffee is the variety of types or types of coffee consumed by the informants (Yuliana, 2015). According to Sitorus in Dewi, Anwar and Amalia, in 2009 there were only a few students who liked pure coffee because they did not like the bitter taste of the coffee and there were dregs. Meanwhile, instant coffee is a dry product that is easily soluble in water, with the composition of coffee, sugar, cream, milk, and other flavor enhancers to give a good taste.

Based on the results interview with the informant about the frequency of coffee consumption in a day following the results of the interview?

"Now it's usually in the morning, but if you want to play outside the house or hang out, it's in the afternoon. So, when I was at the boarding house, I used to stay up late doing my homework."

"I often drink at night, even though I don't have work, around 10 o'clock. In the afternoon it can be counted on the fingers. If there is a lecture morning sometimes if sleepy, just drink coffee"

"Usually consume coffee at 09.00 WIB and 19.00 WIB"

Based on the answers of the informants, it can be said that the amount of coffee consumption for one week is quite frequent, not infrequently it is also combined with chocolate or tea. The category of coffee consumption in this study was consumed two times, morning and night.

Perception symptom is Usually feel bad in the stomach, nausea, dizziness, especially if you consume it on an empty stomach. Based on the results of interviews with informants about the perception of symptoms after consuming coffee, the following are the results of the interviews:

"Feeling tachycardia like a pounding heart if you don't know the type of coffee or the origin of the order"

"Once when you drink coffee, you have an ulcer, so you have to feel rich to drink less coffee. So it's self-conscious to eat first before drinking coffee. But at that time, have you ever drank coffee which has fairly high caffeine content, so the effects you feel are sometimes nervous."

"Usually feel bad in the stomach, nausea, dizziness, especially if you consume it in a stomach state empty." 
Table 1. Results of Interview Data Analysis

\begin{tabular}{|c|c|c|c|c|c|c|}
\hline NO. & QUESTION & MEANING UNITS & CODE & SUB-CATEGORY & CATEGORY & THEME \\
\hline 1. & \multicolumn{6}{|c|}{ Coffee Consumption Pattern } \\
\hline a. & $\begin{array}{l}\text { Do you like coffee? } \\
\text { How many long time } \\
\text { like coffee? }\end{array}$ & $\begin{array}{l}\text { - I like coffee, since 3rd-grade high school until now } \\
\text { - I like coffee, quite like it. But it can be said that I like it } \\
\text { not long ago, just from } 2 \text { nd grade of high school. About } 5 \\
\text { years } \\
\text { - Have liked coffee for } 4 \text { years or since the } 1 \text { st grade of } \\
\text { high school }\end{array}$ & $\begin{array}{ll}- & \text { Yes, for } 5 \text { years } \\
- & \text { Yes, for } 5 \text { years } \\
- & \text { Yes, for } 4 \text { years }\end{array}$ & For 4 - 5 years & $\begin{array}{l}\text { History of likes } \\
\text { coffee }\end{array}$ & \\
\hline b. & $\begin{array}{l}\text { When was the first } \\
\text { time consume } \\
\text { coffee? }\end{array}$ & $\begin{array}{l}\text { - The first time I tried coffee was when I was in } 2 \text { nd grade } \\
\text { of junior high school, but after that, I haven't been too } \\
\text { often } \\
\text { - } \quad \text { High School Class } 2 \\
\text { - } \quad \text { At the 3rd grade of junior high school or } 15 \text { years old }\end{array}$ & $\begin{array}{ll}- & 2014 \\
- & 2016 \\
- & 2015\end{array}$ & Around 2014-2016 & $\begin{array}{l}\text { Early-stage coffee } \\
\text { consumption }\end{array}$ & \\
\hline c. & $\begin{array}{l}\text { How the story } \\
\text { arrives like/used to } \\
\text { consume coffee? }\end{array}$ & $\begin{array}{l}\text { Well at first it was because I saw that my mother likes to } \\
\text { drink coffee, so I wanted to taste it but it was still a } \\
\text { sachet of coffee. The longer it takes to graduate from } \\
\text { high school, he plays quite often at the coffee shop, yes, } \\
\text { to try other coffee flavors. Then there are more and more } \\
\text { coffee shops that are open, so I like to explore types of } \\
\text { coffee that have never been drunk } \\
\text { Maybe someone said, coffee can keep you from falling } \\
\text { asleep, etc. When I was in grade 2, I had a lot of } \\
\text { assignments and a lot of tutoring and thinking about } \\
\text { which college I would like to go to. I guess from there, I } \\
\text { started trying to drink coffee to keep myself from falling } \\
\text { asleep. Continue now it's continuous, like drinking coffee } \\
\text { even though it doesn't make you stay up late } \\
\text { Starting from trial and error and seeing from his father } \\
\text { until now he likes to consume coffee. }\end{array}$ & $\begin{array}{ll}- & \text { Curious } \\
- & \text { Need } \\
- & \text { Curious }\end{array}$ & Curiosity and need & $\begin{array}{l}\text { Journey habit of } \\
\text { coffee } \\
\text { consumption }\end{array}$ & $\begin{array}{l}\text { Coffee } \\
\text { Consumpti } \\
\text { on }\end{array}$ \\
\hline d. & $\begin{array}{l}\text { At what age, you } \\
\text { have a habit } \\
\text { consume coffee? }\end{array}$ & $\begin{array}{ll}- & 18 \text { years } \\
- & 16 \text { years } \\
- & \text { At the age of } 16 \text { years or } 1 \text { st grade of high school or } 2 \text { nd- } \\
\text { grade promotion of high school }\end{array}$ & $\begin{array}{ll}- & 18 \text { years } \\
- & 16 \text { years } \\
- & 16 \text { years }\end{array}$ & Productive age & $\begin{array}{l}\text { Age classification } \\
\text { informant }\end{array}$ & \\
\hline e. & What is Informant's & - If there is no special reason, but rather curious about the & - $\quad$ Habit & Already accustomed & The behavior of & \\
\hline
\end{tabular}




\begin{tabular}{|c|c|c|c|c|c|c|}
\hline NO. & QUESTION & $\begin{array}{c}\text { MEANING UNITS } \\
\end{array}$ & CODE & SUB-CATEGORY & CATEGORY & THEME \\
\hline & $\begin{array}{l}\text { Reason consume } \\
\text { coffee? }\end{array}$ & $\begin{array}{l}\text { taste of coffee that has not been tried and curious about a } \\
\text { coffee shop that has never been visited. } \\
\text { At first, it was just to accompany me to do assignments, } \\
\text { and after a long time it continued } \\
\text { The reason is that you are used to it, delicious and can } \\
\text { improve mood. }\end{array}$ & $\begin{array}{ll}- & \text { Habit } \\
- & \text { Habit }\end{array}$ & & $\begin{array}{l}\text { coffee } \\
\text { consumption }\end{array}$ & \\
\hline f. & $\begin{array}{l}\text { Which type of coffee } \\
\text { is often consumed, is } \\
\text { coffee instant or } \\
\text { pure coffee like } \\
\text { black coffee? }\end{array}$ & $\begin{array}{l}\text { - If you want instant coffee or the current one the } \\
\text { frequency is the same, 50:50 if you're at home brewing } \\
\text { Tora Bika pandemic coffee, but if you leave the house, } \\
\text { you stop by the coffee shop men, the type of coffee is } \\
\text { stronger like Arabian } \\
\text { - Often, coffee sachets are still brewed at home. For } \\
\text { contemporary coffee at certain times. If you're out of the } \\
\text { house or buying online, or just want to buy it } \\
\text { - Likes to consume instant coffee and contemporary } \\
\text { coffee. Drink instant coffee more often (usually the Good } \\
\text { Day brand) }\end{array}$ & $\begin{array}{ll}- & \text { Instant coffee } \\
- & \text { Instant coffee } \\
- & \text { Instant coffee }\end{array}$ & consumption & Coffee type & \\
\hline g. & $\begin{array}{l}\text { How many glasses } \\
\text { amount of coffee is } \\
\text { consumed during a } \\
\text { week? }\end{array}$ & $\begin{array}{l}\text { It depends on the mood, maybe } 3 \text { times a week, } \\
\text { sometimes I like to mix it if I drink coffee the next day } \\
\text { it's chocolate/the like that } \\
\text { - Usually drink in a week } 7-10 \text { times, } 1 \text { day at least once } \\
\text { - During the pandemic, in a week consume as much as } 3 \\
\text { cups of coffee. }\end{array}$ & $\begin{array}{ll}\text { - } & 3 \text { cups/week } \\
\text { - } & 7-10 \text { glasses/week } \\
\text { - } & 3 \text { cups/week }\end{array}$ & $\begin{array}{l}\text { Don't exceed the } \\
\text { recommended limit }\end{array}$ & $\begin{array}{l}\text { Recommendation } \\
\text { limit of coffee } \\
\text { consumption }\end{array}$ & \\
\hline h. & $\begin{array}{l}\text { At what time You } \\
\text { consume coffee? }\end{array}$ & $\begin{array}{l}\text { - Now it's usually in the morning, but if you want to play } \\
\text { outside the house or hang out, it's in the afternoon. Well, } \\
\text { when I was at the boarding house I used to stay up late } \\
\text { doing my homework } \\
\text { Often drink at night, even though there is no work, } \\
\text { around } 10 \text { am drinking. In the afternoon it can be counted } \\
\text { on the fingers. If there is a morning lecture, sometimes if } \\
\text { you are sleepy, just drink coffee } \\
\text { Usually consumes coffee at } 09.00 \text { A.M and 7.00 P.M }\end{array}$ & $\begin{array}{ll}- & \text { Morning and evening } \\
- & \text { Morning and night } \\
- & \text { Morning and night }\end{array}$ & Consuming in 2 times & $\begin{array}{l}\text { Time of coffee } \\
\text { consumption }\end{array}$ & \\
\hline i. & $\begin{array}{l}\text { Are Informants exist } \\
\text { intention to reduce } \\
\text { coffee consumption? }\end{array}$ & $\begin{array}{l}\text { - There are so many because I feel like I've consumed too } \\
\text { much } \\
\text { The intention must be there because girls are not that } \\
\text { good if for example drinking coffee too often because I }\end{array}$ & 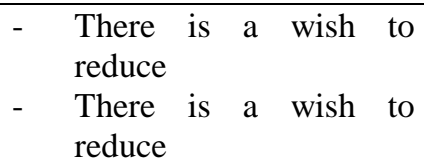 & $\begin{array}{l}\text { Desire reduce coffee } \\
\text { consumption }\end{array}$ & $\begin{array}{l}\text { Desire changed of } \\
\text { coffee } \\
\text { consumption }\end{array}$ & \\
\hline
\end{tabular}




\begin{tabular}{|c|c|c|c|c|c|c|}
\hline NO. & QUESTION & MEANING UNITS & CODE & SUB-CATEGORY & CATEGORY & THEME \\
\hline & & $\begin{array}{l}\text { have read that the risk can be higher for women. But it is } \\
\text { still difficult to reduce because it is still a habit. } \\
\text { - Shortly, I still don't intend to reduce my coffee } \\
\text { consumption }\end{array}$ & - $\quad$ No desire to reduce & & & \\
\hline $\mathrm{j}$. & $\begin{array}{l}\text { After drinking } \\
\text { coffee What is felt } \\
\text { by your body? }\end{array}$ & $\begin{array}{l}\text { - Feeling tachycardia, like a pounding heart, if you don't } \\
\text { know the type of coffee or where you ordered it } \\
\text { - Once when you drink coffee, you have an ulcer, so you } \\
\text { have to feel rich to drink less coffee. So it's self- } \\
\text { conscious to eat first before drinking coffee. But at that } \\
\text { time, have you ever drank coffee which has fairly high } \\
\text { caffeine content, so the effect you feel is sometimes } \\
\text { overwhelming } \\
\text { Usually feel bad in the stomach, nausea, dizziness, } \\
\text { especially if you consume it on an empty stomach. }\end{array}$ & 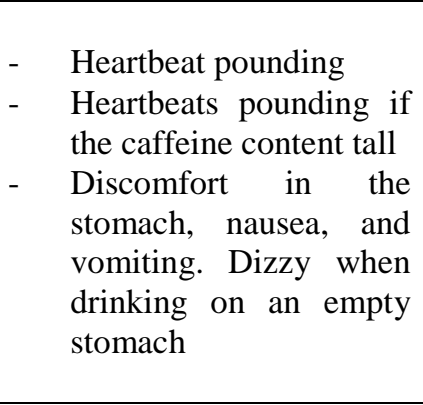 & $\begin{array}{l}\text { Side effects in medium } \\
\text { level }\end{array}$ & Side effects & \\
\hline $\mathrm{k}$. & $\begin{array}{l}\text { How often do you } \\
\text { come to a coffee } \\
\text { shop during the time } \\
\text { of pandemic } \\
\text { COVID-19? }\end{array}$ & $\begin{array}{l}\text { - Oh, it's so often hahaha, when I'm on vacation, it's often } \\
\text { from Friday to Monday. } \\
\text { - During the pandemic, I just recently came to the coffee } \\
\text { shop, to eat or drink there. Previously, it was only take } \\
\text { away or online only } \\
\text { - Not often, only come to the coffee shop once. }\end{array}$ & $\begin{array}{l}\text { - Often, every week to } \\
\text { the coffee shop } \\
\text { - } \text { Often to the coffee shop } \\
\text { - Not often, only } 1 \text { time } \\
\text { to the coffee shop }\end{array}$ & Relative often & Frequency visit & \\
\hline 1. & $\begin{array}{l}\text { According to you, } \\
\text { how is the health } \\
\text { protocol standard } \\
\text { that runs in the } \\
\text { coffee shop? }\end{array}$ & $\begin{array}{l}\text { - It depends on the coffee shop, for example, coffee shop } \\
\text { A is a well-known coffee shop, right? But if it's an } \\
\text { ordinary coffee shop and it's not too viral, the procedure } \\
\text { is just a formality. } \\
\text { The process is pretty good if it's in the Jakarta area. For } \\
\text { the time of the pandemic, also in the Bintaro area, the } \\
\text { process is still standard. If it's an ordinary coffee shop, } \\
\text { it's usually just an ordinary formality for the process } \\
\text { The procedures in the coffee shop are by the } \\
\text { recommendations. }\end{array}$ & $\begin{array}{l}\text { - Mostly already applied } \\
\text { health protocol but } \\
\text { some others are just a } \\
\text { formality } \\
\text { Mostly already applied } \\
\text { health protocol but } \\
\text { some others are just a } \\
\text { formality } \\
\text { Health protocol already } \\
\text { such that recommended }\end{array}$ & Just a formality & $\begin{array}{l}\text { Health protocol } \\
\text { standard } \\
\text { COVID-19 }\end{array}$ & \\
\hline 2. & Informant's & & & & & \\
\hline a. & $\begin{array}{l}\text { According to you, is } \\
\text { it during pandemic } \\
\text { COVID-19 coffee } \\
\text { consumption you }\end{array}$ & $\begin{array}{l}\text { - Increasing, because I play more often and many of my } \\
\text { friends open a coffee shop business } \\
\text { - During the pandemic it increases than usual, at the } \\
\text { beginning of the pandemic it can be } 2 \text { times in } 1 \text { day in }\end{array}$ & $\begin{array}{l}\text { Yes, Experiencing } \\
\text { enhancement coffee } \\
\text { consumption because of } \\
\text { holidays and the }\end{array}$ & $\begin{array}{l}\text { Relatively experienced } \\
\text { enhancement }\end{array}$ & $\begin{array}{l}\text { Enhancement } \\
\text { coffee } \\
\text { consumption }\end{array}$ & $\begin{array}{l}\text { Coffee } \\
\text { Consumpti } \\
\text { on }\end{array}$ \\
\hline
\end{tabular}




\begin{tabular}{|c|c|c|c|c|c|c|}
\hline NO. & QUESTION & MEANING UNITS & CODE & SUB-CATEGORY & CATEGORY & THEME \\
\hline & become increase? & $\begin{array}{l}\text { the morning and if you want to stay up drinking coffee at } \\
\text { night too } \\
\text { During the pandemic, the coffee consumption did not } \\
\text { increase because it was also interspersed with drinking } \\
\text { herbal tea }\end{array}$ & $\begin{array}{l}\text { influence of relatives } \\
\text { Yes, Experiencing } \\
\text { enhancement coffee } \\
\text { consumption out of } \\
\text { necessity require it to } \\
\text { stay awake } \\
\text { Not experiencing } \\
\text { enhancement }\end{array}$ & & & \\
\hline b. & $\begin{array}{l}\text { According to you, is } \\
\text { the environment } \\
\text { around (like friends, } \\
\text { family, relatives) to } \\
\text { experience } \\
\text { enhancement coffee } \\
\text { consumption during } \\
\text { a pandemic COVID- } \\
19 \text { ? }\end{array}$ & $\begin{array}{l}\text { In my opinion, yes, because since the Tiktok App, many } \\
\text { hidden gems make people curious to go to the coffee } \\
\text { shop and buy the coffee. But if you look at me no, } \\
\text { because he already has his schedule for coffee only once } \\
\text { a day } \\
\text { Turns out it's not just me, my cousin who happens to live } \\
\text { together also increases his coffee } \\
\text { Coffee consumption in the surrounding environment is } \\
\text { normal, does not change/does not increase. }\end{array}$ & $\begin{array}{l}\text { - Yes, increase due to } \\
\text { influence social media } \\
\text { promote the coffee shop } \\
\text { - Yes, increase due to } \\
\text { influence social from a } \\
\text { sibling } \\
\text { - In the neighborhood a } \\
\text { bit not experience } \\
\text { enhancement of coffee } \\
\text { consumption }\end{array}$ & $\begin{array}{l}\text { Relatively experienced } \\
\text { enhancement }\end{array}$ & $\begin{array}{l}\text { Enhancement } \\
\text { coffee } \\
\text { consumption }\end{array}$ & \\
\hline c. & $\begin{array}{l}\text { According to you, } \\
\text { what is the reason } \\
\text { people the } \\
\text { (environment } \\
\text { around) consume } \\
\text { coffee? }\end{array}$ & $\begin{array}{l}\text { Maybe because someone is a coffeeholic, so he really } \\
\text { explores all types of coffee, then maybe someone needs } \\
\text { to drink coffee to do college or office assignments, or the } \\
\text { reason is just that I'm curious from the TikTok app } \\
\text { earlier. } \\
\text { Need to stay up late doing assignments, besides that } \\
\text { because the environment is like playing, or going out } \\
\text { with friends, so often when you hang out you buy coffee, } \\
\text { so you have a habit of consuming coffee. The } \\
\text { environment around me also consumes coffee because it } \\
\text { relieves stress } \\
\text { The reason for the surrounding environment is that they } \\
\text { are used to drinking coffee and are curious to try coffee } \\
\text { at a different coffee shop. }\end{array}$ & $\begin{array}{l}\text { - The reasons are various } \\
\text { because indeed fanatic } \\
\text { of coffee of necessities } \\
\text { to stay up late } \\
\text { - The reason is that circle } \\
\text { influence friendship and } \\
\text { stress reliever } \\
\text { The reason is that used } \\
\text { to drink coffee and } \\
\text { curios want to try coffee } \\
\text { at the different coffee } \\
\text { shop }\end{array}$ & $\begin{array}{l}\text { Influenced so that it } \\
\text { arises habit }\end{array}$ & $\begin{array}{l}\text { Trigger of coffee } \\
\text { consumption }\end{array}$ & \\
\hline
\end{tabular}


Based on the results interview, The category of symptom perception in this study consisted of several categories, namely heart palpitations, stomach problems, nausea, and dizziness after consuming coffee.

Health Protocol Compliance is a series of rules and provisions that must be followed by all parties to carry out their activities safely on moment pandemic COVID-19. Based on the results of interviews with an informant about protocol compliance health on the coffee shop which visited, here are the results of the interview:

"It depends on the coffee shop, for example, coffee shop A is a famous coffee shop, so he does a very good job. But if it's an ordinary coffee shop and it's not too viral, the procedure is just a formality"

"The process is pretty good if it's in the Jakarta area. For the time of the pandemic, also in the Bintaro area, the process is still standard. If it's an ordinary coffee shop, it's usually just an ordinary formality for the procedure"

"The procedure at the coffee shop is by the recommended of COVID-19 health protocol standard"

Based on results interview to informants, compliance with the health protocols carried out by the coffee shops visited were up to standard. Usually, at the coffee shop the prokes (health protocols) are carried out only as a formality.

Based on the results and discussion of the study, it can be concluded that the pattern of coffee consumption in the age group productive attends increases. Usually consumed in the morning and evening or morning and evening. The amount of coffee consumed by the informants is quite varied who consume 3 glasses in a week, and there is also which consume 7-10 glasses in a week. This happens because of the rise of coffee shops circulating, hangouts on weekends, and the consumption of instant coffee that is made home alone.

By because of that we recommend the following things, in consuming coffee make sure the stomach is not empty (have breakfast/ eat first) so you don't feel nauseous while consuming coffee, you should consume coffee according to your abilities and capacities, the need for self-awareness to keep a healthy lifestyle by consuming a nutritious and balanced diet, do physical activity, and consume enough water. Besides that, dissemination of information using a variety of alternative media regarding coffee consumption within safe limits and its effects on the body both internally and externally short term and long term long need doing specifically to productive age groups and the general public who often make coffee as a lifestyle today to regulate consumption patterns properly.

\section{REFERENCES}

Bellah, R. (2018) Coffee Consumption, Nutritional Status and Blood Pressure in Fishing Community in Puger Kulon and Puger Wetan Villages (Study in Puger Kulon and Puger Wetan Villages, Puger District, Jember Regency). The University of Jember. 
Proceeding The First

Muhammadiyah Internasional-

Public Health and Medicine

Conference

Dewi, FI, Anwar, F. and Amalia, L. (2009) 'Perceptions of Coffee and Tea Consumption of TPB-Ipb Students', Journal of Nutrition and Food, 4(1), pp. 20-28.

Herlyana, E. (2012) 'Coffee Shop Phenomenon as Symptoms of Youth's New Lifestyle', ThaqÃfiyy ÃT, 13(1), pp. 188-204. International Coffee Organization (2020) Trade Statistics Tables, International Coffee Organization.

Kadita, F. (2017) Relationship of Coffee Consumption and Screen-Time with Sleep Length and Nutritional Status in Adults. Diponegoro University, Semarang.

Kurniawan, CN, Wahyu, EE and Nurbaya, S. (2020) 'Integrative Review of the Covid-19 Pandemic and Impact on the Beverage Industry Coffee', National Seminar on Business Administration and Management, 6(October), pp. 21-30.

Meliala, RRASD (2017) 'Coffee consumption rates by income, age, and price in Depok', Thesis, pp. $1-159$.

Oktaviani, K. (2018) Coffee as a Young People's Lifestyle Study: At the 'Coffee Room' Coffee Shop Customers in Bogor City, Jakarta State University Repository.

Olivia, S., Gibson, J. and Nasrudin, R. (2020) 'Indonesia in the Time of Covid-19', Bulletin of Indonesian Economic Studies, 56(2), pp. 143-174. two: 10.1080/00074918.2020.1798581.

Prasodjo, A. (2016) 'LIFESTYLE OF COFFEE STOP CONSUMERS IN JEMBER REGENCY', Proceedings of the National Seminar, pp. 133-143.

Yuliana, EEN (2015) The Relationship of Coffee Consumption and Hypertension in the Elderly. Sebelas Maret State University, Surakarta. 